\title{
TWO MISSIONS OF MAJOR HIERONYMUS NATALIE TO ISTANBUL: DIPLOMATIC CONTACTS BETWEEN RUSSIA AND THE OTTOMAN EMPIRE IN 1715-1718 ${ }^{1}$
}

\author{
Tatyana A. Bazarova \\ Scientific and Historical Archive of Saint Petersburg Institute of History, RAS, \\ Saint Petersburg, Russian Federation
}

\begin{abstract}
Introduction. Diplomatic contacts between Russia and the Ottoman Empire between Adrianople (1713) and Constantinople (1720) treaties are explored. For Posolsky prikaz (Ambassadorial office), the main task was to keep peaceful relations between Russia and the Ottoman Empire, which gave the possibility to the tsar to concentrate on military operations in Pomerania. Methods. The study is based on the analysis of unpublished materials of the Posolsky prikaz and their comparison with notes of contemporaries and with other historical sources. Analysis and results. The absence of Russian diplomatic resident in Istanbul did not promptly allow to solve the problems caused by violations of the conditions of the Adrianople treaty: border conflicts and the entry of the tsarist army into Poland. After the Treaty of Passarowitz (1718), which ended the war of the Ottoman Empire with Venice and Austria, a new danger arose for the beginning of the Russo-Turkish war. In 1715 and 1718, the Ragusin on the Russian service Hieronymus Natali was twice sent to the Sublime Porte with the charters of Peter I. Along with handing the tsar's charters to the Grand Vizier about border conflicts, Natalie had secret assignments connected with the prevention of a military conflict with the Ottoman Empire.

Key words: Russian-Turkish relations, the first quarter of $18^{\text {th }}$ century, Peter the Great, diplomacy, peace negotiations, the Ottoman Empire, Pomerania.

Citation. Bazarova T.A. Two Missions of Major Hieronymus Natalie to Istanbul: Diplomatic Contacts Between Russia and the Ottoman Empire in 1715-1718. Vestnik Volgogradskogo gosudarstvennogo universiteta. Seriya 4, Istoriya. Regionovedenie. Mezhdunarodnye otnosheniya [Science Journal of Volgograd State University. History. Area Studies. International Relations], 2019, vol. 24, no. 1, pp. 84-97. (in Russian). DOI: https://doi.org/10.15688/ jvolsu4.2019.1.7
\end{abstract}

УДК 94(470)+929Петр(470)*1

ББК 63.3(2)511

Дата поступления статьи: 03.10.2018

Дата принятия статьи: 28.11.2018

\section{ДВЕ ПОЕЗДКИ МАЙОРА ИЕРОНИМА НАТАЛИ В СТАМБУЛ: ДИПЛОМАТИЧЕСКИЕ КОНТАКТЫ РОССИИ И ОСМАНСКОЙ ИМПЕРИИ В 1715-1718 ГОДАХ ${ }^{1}$}

\footnotetext{
Татьяна Анатольевна Базарова

Научно-исторический архив и группа источниковедения СПбИИ РАН, г. Санкт-Петербург, Научно-исторический архив и группа источниковедения Спй
Российская Федерация

Аннотация. Исследуются дипломатические контакты России и Османской империи между Адрианопольским (1713) и Константинопольским (1720) договорами. Перед Посольским приказом стояла задача сохранить мирные отношения России с Османской империей, что позволяло царю сконцентрироваться на военных действиях в Померании. Отсутствие русского резидента в Стамбуле не давало возможности оперативно решить проблемы, вызванные нарушениями условий Адрианопольского договора:
} 
пограничными конфликтами и вводом царского войска в Польшу. После Пожаревацкого (Пассаровицкого) конгресса (1718), завершившего войну Османской империи с Венецией и Австрией, появилась новая опасность начала русско-турецкой войны. В 1715 и 1718 гг. с грамотами Петра І к Высокой Порте дважды отправляли рагузинца на русской службе Иеронима Натали. Исследование делопроизводственных материалов Посольского приказа показало, что помимо вручения царских грамот великому везиру у Натали были секретные поручения, связанные с необходимостью не допустить военный конфликт с Османской империей.

Ключевые слова: русско-турецкие отношения, первая четверть XVIII в., Петр Великий, дипломатия, мирные переговоры, Османская империя, Померания.

Цитирование. Базарова Т. А. Две поездки майора Иеронима Натали в Стамбул: дипломатические контакты России и Османской империи в 1715-1718 годах // Вестник Волгоградского государственного университета. Серия 4, История. Регионоведение. Международные отношения. - 2019. - Т. 24, № 1. - C. 84-97. - DOI: https://doi.org/10.15688/jvolsu4.2019.1.7

Введение. 13 июня 1713 г. в Адрианополе (Эдирне) между Россией и Османской империей был заключен мирный договор, который завершил Русско-турецкую войну 1710-1713 годов. По условиям Адрианопольского мира Россия утратила возможность иметь постоянную дипломатическую миссию в османской столице ${ }^{2}$. После отъезда из Стамбула в сентябре 1714 г. чрезвычайных полномочных послов П.П. Шафирова и М.Б. Шереметева в течение нескольких лет официальные контакты между двумя государствами осуществлялись через отправку представителей с дипломатическими поручениями «без характера» (без верительной грамоты). Россия дважды - в 1715 и 1718 гг. - посылала с царскими грамотами в Османскую империю Иеронима Натали. В 1718 г. в Санкт-Петербурге впервые побывал представитель Высокой Порты - Мустафа-ага [1, с. 320-321]. В следующем, 1719 г., посланнику А.И. Дашкову удалось склонить османское правительство начать переговоры, которые привели к подписанию Константинопольского «вечного мира» (1720), восстановившего право России на дипломатическую миссию в Стамбуле.

Методы, материалы. Если дипломатическая история русско-турецкой войны (1711-1713) и переговоры А.И. Дашкова с Высокой Портой (1719-1720) о заключении Константинопольского мира уже становились предметом исследования [27; 45, с. 277-283; $20 ; 21 ; 23$, с. 294-305, 395-396; 24, с. 256-260], то попытки русского правительства в середине 1710-х гг. восстановить постоянные контакты с Османской империей историки оставили практически без внимания. Так, фундамен- тальное исследование С.Ф. Орешковой о русско-турецких отношениях в начале XVIII в., хронологически доведено только до 1714 г. [27]. Исследовательница пропустила период между Адрианопольским и Константинопольским миром и во второй своей монографии [28]. Кратко упомянувшие о поездках И. Натали в Стамбул Т.К. Крылова и Л.А. Никифоров основное внимание уделили влиянию на османскую политику западноевропейских держав, а также анализу царских грамот [21, с. 277-278; 24, с. 251-259]. Между тем сведения о возложенных на И. Натали задачах и пребывании при османском дворе имеются в делопроизводственных документах Посольского приказа и переписке майора с канцлером Г.И. Головкиным и вице-канцлером П.П. Шафировым, отложившихся в фонде 89 (Сношения России с Турцией) РГАДА. Их дополняют мемуары переводчика голландского посольства при Порте Виллима Тейлса [48]. Изучение данных материалов позволяет выявить основные проблемы русско-турецких отношений в середине 1710-х годов.

Анализ. После размежевания границ и ратификации Адрианопольского мира (1713) политические противоречия между Россией и Османской империей на время потеряли свою остроту. Правительства обеих держав переключили внимание на решение проблем в разных регионах Европы. В декабре 1714 г. султан Ахмед III объявил войну Венецианской республике. Главной целью Высокой Порты стала Морея (п-ов Пелопоннес), переданная венецианцам по условиям Карловицкого мира (1699). В 1715 г. османы направили к ее берегам свой флот и в течение двух месяцев заня- 
ли весь полуостров [26, с. 769-770]. Высокая Порта старалась склонить противника к скорейшему заключению мира и с этой целью запретила венецианцам торговать во всех турецких владениях [21, с. $277 ; 48$, с. 258-265]. Однако венецианский дож вместо мирных переговоров обратился за военной помощью к императору Священной Римской империи германской нации Карлу VI. После того как 13 апреля 1716 г. Империя и Венеция заключили оборонительный и наступательный союз, Османской империи пришлось противостоять военной мощи двух держав.

Петр I после одержанных в 1714 г. русским флотом побед на Балтийском море начал подготовку к кампании в Померании. Летом 1715 г. датский и прусский короли осадили Штральзунд, оборону которого возглавлял шведский король Карл XII. 9 июля 1715 г. царь заключил с датчанами конвенцию о совместных действиях и условиях содержания русского корпуса [4, с. $256 ; 45$, с. 41-43], после чего уведомил датского и прусского королей о начале похода войска в Померанию через польские земли [4, с. 256; 6, л. 69-73]. 27 июля генерал-фельдмаршал Б.П. Шереметев получил царский указ немедленно следовать к армии $[50$, л. 68]. Однако вскоре среди союзников начались разногласия. Армия Б.П. Шереметева замедлила свой марш и остановилась в Польше, где обострился конфликт Августа II со шляхтой. Русские полки так и не приняли участие в померанской кампании: в декабре 1715 г. Штральзунд был взят прусско-датскосаксонскими войсками [45, с. 43$]$.

Анализируя цели отправки Иеронима Натали к Высокой Порте осенью 1715 г., историки нередко упускают из виду «померанский фактор». Так, Т.К. Крылова отметила, что Петр I попытался воспользоваться благоприятной международной обстановкой для «установления в Константинополе постоянного русского дипломатического поста» [21, с. 277]. Л.А. Никифоров полагал, что основной задачей было вручение царской грамоты с жалобой на набег «кубанцев и ногайцев» [25, с. 257; 19, л. 16]. Действительно, в феврале 1715 г. кубанский сераскер Бахти-Гирей предпринял поход в Нижнее Поволжье, разорив улусы Калмыцкого ханства. В мае того же года кубанские татары совершили набег на окрест- ности Астрахани [49, с. 72-76]. В том же году крымские татары напали на земли донских казаков, а также Харьковского и Изюмского полков. Согласно 8-му пункту Адрианопольского договора надлежало найти и наказать виновных, а также вернуть пострадавшей стороне полон и награбленное имущество [32, с. $180-186 ; 37$, с. $36-43]$. Необходимость оперативного расследования приграничных инцидентов стала основным аргументом русского правительства для убеждения Высокой Порты разрешить иметь секретаря или резидента в Стамбуле.

Вступление армии Б.П. Шереметева в польскую землю противоречило условиям Адрианопольского договора 1713 года. Его первый пункт гласил: «...когда его царское величество и его войски похотят возвратиться из Померании, да пройдут все в Россию подле границы другой стороны Польши одинажды до России, а впредь более никогда не иметь проходить чрез Польшу в Померанию» [37, с. 38 39]. В 1714 г. возвращавшаяся из Померании армия уже использовала право «одинажды» пройти по территории Польши. В Санкт-Петербурге рассчитывали, что воевавшая с Венецией Османская империя не пойдет на открытое обострение отношений со своим северным соседом. Тем не менее русское правительство не могла не тревожить негативная реакция турецкого правительства на нарушение одного из важнейших условий договора. По словам В. Тейлса, Высокая Порта, «хотя сие за обиду почитала, токмо опасаясь нападения от цесаря, принуждена была обиду сию скрывать» [48, c. 255]. Руководство Посольского приказа сочло необходимым послать гонца в Стамбул, чтобы еще раз заверить султана в намерении царя сохранить с ним мирные отношения. Царские грамоты было поручено доставить рагузинцу майору Иерониму Натали.

Биография И. Натали историкам почти не известна. Некоторые факты о его военной службе содержит составленная в апреле 1721 г. офицерская «сказка». Так, в 1709 г. Иероним Марков сын Натали (Денатали) доставил царю письма посла при османском дворе П.А. Толстого и был принят капитаном в пехотный полк дивизии А.И. Репнина. В 1714 г. он получил майорский «аттестат» и служил секунд-майором во Втором гренадер- 
ском полку. В 1716 г. по возвращении из Стамбула И. Натали выехал в Мекленбург. 27 июня того же года именным указом Петра I он был пожалован в подполковники. В январе 1718 г. И. Натали определили в Тверской драгунской полк. Однако к месту службы он прибыл только в феврале 1719 г., уже после второй поездки в Стамбул [30, с. 869].

Отправка профессионального военного с царскими грамотами к иностранному двору широко практиковалась в петровское время. Так, в том же 1715 г. с дипломатическим поручением в Англию прибыл гвардии капитан С.Г. Нарышкин, к датскому королю Фредерику IV был послан гвардии капитан П.И. Ягужинский $[4$, с. 129, 256], а во главе посольства в Персию поехал подполковник А.П. Волынский. Надо полагать, что на выбор кандидатуры И. Натали повлияли два важных обстоятельства: свободное владение итальянским языком международного общения в Стамбуле, а также опыт поездок в османскую столицу (в 1712 г. капитан И. Натали доставлял царские грамоты русским послам П.П. Шафирову и М.Б. Шереметеву) [31, с. 101, 131, 370, 392, 396].

По-видимому, замысел послать гонца в Стамбул появился за несколько месяцев до вступления русской армии в Польшу. В апреле 1715 г. И. Натали вызвали из Риги в Посольскую канцелярию, при которой он «обретался» в течение нескольких месяцев [43, л. 64] ${ }^{3}$. Наконец, 6 октября в Санкт-Петербурге были подготовлены основные документы для «экспедиции в турскую землю»: две грамоты султану («о обидах с турской стороны» и «о войсках, отпущенных в Германию»), грамота великому везиру «о обидах», инструкция «что ему тамо чинить», зашифрованная секретная мемория, паспорт «о проезде турскою землею», «цифирная азбука» по-итальянски ${ }^{4}$, а также письмо к киевскому губернатору Д.М. Голицыну о предоставлении провожатых до Бендер и двух рейтар для курьерской службы [43, л. 64-64 об.].

Состоявшая из пятнадцати пунктов инструкция касалась официальной стороны миссии. И. Натали надлежало добиваться незамедлительного ответа Высокой Порты на царские грамоты, создания комиссии для расследования пограничных конфликтов, а также разрешения прислать резидента или секретаря для постоянного пребывания при османском дворе. Во время аудиенции с везиром майору следовало объявить, что «его царского величества никогда никакова намерения нет с Портою Оттоманскою мир разорвать... и венецияном вспомогать не будет» [19, л. 23-25]. Войско же было отправлено в немецкие земли по просьбе английского, датского и прусского королей для действий против Карла XII [19, л. 26-27].

Русское правительство рассчитывало, что послы дружественных европейских держав в Стамбуле помогут заверить Порту в том, что царь не нарушит мир с Османской империей, и смягчить ее реакцию на вступление армии в Польшу. Вице-канцер П.П. Шафиров подготовил письма английскому послу Р. Саттону, а также голландскому послу Я. Кольеру и его первому переводчику В. Тейлсу, призвав их содействовать русским интересам.

Тесные контакты с Р. Саттоном и Я. Кольером установил первый постоянный посол России при Высокой Порте П.А. Толстой еще в начале правления султана Ахмеда III (17031730). Англичанин с голландцем выступали посредниками на переговорах П.П. Шафирова и М.Б. Шереметева с Высокой Портой, которые привели к заключению Константинопольского мира (5 апреля 1712 г.). После отъезда русских дипломатов из Стамбула в сентябре 1714 г. голландский посол и его переводчик продолжали переписываться с Г.И. Головкиным и П.П. Шафировым, сообщая об изменениях политики османского правительства и происшествиях при дворе.

В отличие от голландцев Р. Саттон уже весной 1713 г. по распоряжению своего правительства отказался от помощи русским послам при Порте. От контактов с ними устранился и переводчик английского посольства рагузинец Лука Барка, которого русские послы считали лучшим своим помощником в Стамбуле и прочили на место резидента [2, c. 55,60$]$. На английскую позицию повлияло изменение баланса сил в Европе. Северные союзники приступили к активным действиям в Померании; с ними стала сближаться Пруссия. Петр I новыми победами на европейском театре военных действий укрепил свое политическое влияние, пошатнувшееся после не- 
удачного Прутского похода. Дальнейшее усиление России при одновременном ослаблении позиции Швеции на Балтике противоречило интересам британского правительства. Завершившие войну за Испанское наследство (1701-1714) Утрехтский (1713) и Раштаттский (1714) мирные договоры утвердили принцип политического равновесия в Европе, а конфликт на Севере грозил его нарушить [3, c. 233-236].

Вступление в 1714 г. на английский престол Георга I (являвшегося одновременно и ганноверским курфюрстом) привело к временному улучшению отношений между Великобританией и Россией. 17 (28) октября 1715 г. Ганновер и Россия заключили Грейфсвальдский союзный договор ${ }^{5}$. Георг I не был заинтересован в новом русско-турецком военном конфликте, который мог отвлечь Петра I от действий в Шведской Померании. Еще в январе 1715 г. русский посол в Лондоне Б.И. Куракин добился отправки королевского указа Р. Саттону, чтоб тот интересы царского величества «во всем престерегал и в постоянном бы мире Порту содержал» [35, л. 550-551 об.].

Со своей стороны, вице-канцлер П.П. Шафиров в письме английскому послу подчеркивал, что извещение Порты о проходе российских войск в Германию «по крепким о том учиненным домогателствам от союзных его царского величества» через польские земли являлось основной «причиной комисии» майора [36, л. 53 об.] $]^{6}$. Рассчитывая на «продолжание дружбы», П.П. Шафиров попросил повлиять на великого везира, «дабы сей марш от Оттоманской Порты за противно принят не был», поскольку «его величество король Великобританской сам у его царского величества о посылке тех войск в Померанию усилно домогался» [36, л. 53 об. - 54]. Однако судя по тому, что в секретной инструкции майору рекомендовалось на Р. Саттона «вовсе не надеется» и осторожно обходиться с его переводчиком Лукой Баркой [44, л. 3], у руководства Посольского приказа оставались сомнения, что действия англичан при Порте будут полезны российским интересам.

Во время пребывания в османской столице И. Натали также надлежало «проведывать... что тамо в воинских и других делах чинится» $[44$, л. 3$]$. Содействовать ему в вы- полнении этой задачи должны были корреспонденты («приятели») русского правительства в Стамбуле. По прибытии в Стамбул майору следовало немедленно связаться с В. Тейлсом и архиепископом Анцыры рагузинцем Кириллом Галани, которые помимо «наставлений» могли помочь в доставке к царскому двору зашифрованных посланий [44, л. 3 об.]. И. Натали было поручено «при случае секретно самому подать» (или через толмача) письмо первому переводчику Порты Ионакию Маврокордато и просить его о «вспоможении». Майору также следовало доставить «приятелям» значительную сумму денег, в том числе «погодную дачу» голландскому послу Я. Кольеру и великому драгоману Ионакию Маврокордату - по 1000 венецианских золотых червонцев [40, л. 1, 3 об.]. Переводчику В. Тейлсу также полагалось «за издержки ево во время бытия за салтаном в компании сего 1715-го, куда он для престережения интересов его царского величества ездил, и на другие ему чрезвычайные росходы пятьсот червонных золотых» $[41, \text { л. } 2]^{7}$.

Если основные документы, связанные с отправкой майора в Стамбул, подготовили в Посольской канцелярии в Санкт-Петербурге, то материальная сторона поездки и отбор сопровождающих были возложены на Посольский приказ в Москве. Бюджет посольства составили суммы, предназначенные для выплаты жалованья И. Натали и его свите, а также для компенсации дорожных расходов и подарков. Так, по царскому указу от 30 сентября 1715 г., «для той посылки на проезд в оба пути и для тамошняго жития на иждивение» майору выделили 1500 золотых червонцев и «на роздачу тамо от дел соболей и другой рухляди мяхкой на триста рублев», взятых в Сибирском приказе [40, л. 1; 46, л. 7-8]. В Москве в свиту майора определили подьячих, курьеров, а также толмача Посольского приказа Константина Дмитриева ${ }^{8}$ (его жалованье составило 150 рублей). Под казну и сопровождавших И. Натали людей выделили шестнадцать подвод. Поиск и покупка в Москве голландских и венецианских червонцев заняли много времени, и майор смог двинуться в путь только поздней осенью. 12 декабря он прибыл в Киев, а 26 декабря сообщил из Бендер, что вынужден задержаться: прежний паша две 
недели назад был «удавлен», а нового еще не назначили. В турецкой пограничной крепости уже ходили слухи о многотысячном русском войске в Польше [13, л. 75].

Проведя почти месяц в Бендерах [39, л. 2], майор прибыл в Стамбул 2 февраля 1716 г. [11, л. 7]. Через несколько дней, 8 февраля, И. Натали вручил царские грамоты великому везиру Силахдару Дамаду Али-паше и, согласно инструкции, попросил назначить еще одну встречу, чтобы «изустно говорить». По словам майора, принят он был «зело с малою или никакою церемониею, токмо учтивость получил от везиря в одном кавтане» [11, л. 10 об.]. На вопрос Али-паши о местонахождении царя И. Натали ответил, что государь ныне в Санкт-Петербурге [11, л. 77 об.]. Между тем это уже не соответствовало действительности. 27 января 1716 г. Петр I покинул берега Невы и направился через Прибалтику в Гданьск, где располагалась армия Б.П. Шереметева. В марте 1716 г. Петр І стал посредником в деле примирения Августа II и Тарногрудской конфедерации, образованной в 1715 г. с целью борьбы с саксонским влиянием и низложения короля. Одновременно в Гданьске проходили встречи с дипломатами герцога Мекленбург-Шверинского Карла-Леопольда. Впрочем, до Стамбула известия об отбытии царя из России пока не дошли.

В первый же день пребывания в Стамбуле И. Натали «секретно уведомил» о своем прибытии голландского переводчика В. Тейлca, который не замедлил посетить русский посольский двор. Получивший «погодную дачу» и письма голландец пообещал «чинить сердечное споможение в ынтересах царского величества» $[9 \text {, л. 10-10 об. }]^{9}$. Сразу после ухода В. Тейлса османы поставили возле русского посольского двора охрану - отряд янычар из восемнадцати человек и трех чаушей ${ }^{10}$ [29, л. 13]. Как писал И. Натали, «внезапно меня секвестровали в моем доме, чтоб не мог ни с кем иметь комуникации» [11, л. 7]. На неправомерность ограничения своей свободы (Россия не находились в состоянии войны с Ocманской империей, да и полномочий на ведение переговоров он не имел) майор сначала указал рейс-эфенди (реиз-эфенди) [11, л. 7 об.], а затем поднял этот вопрос во время встречи с Ионакием Маврокордато. Получив ответ драгомана, что «такою ж манерою и с персицкими послами поступают» [11, л. 9], И. Натали сделал вывод о причине своего «утеснения»: «чтоб я усматривать не мог турецких поступок, имея оные великое подозрение о моем приезде» [9, л. 10 об. - 11]. В. Тейлс в своих записках также отметил, что «майора принимают так, будто бы его царское величество открытой был неприятель Порте» [48, c. 278-279].

К Порте не допускали переводчика, поэтому свои сообщения майор передавал через чауша. Служителям майора позволялось «в Цареграде за караулом ходить, но на Галату ${ }^{11}$ весма заказано» [10, л. 12]. Однако после получения русских мехов стоявшие на карауле чауши стали более благосклонны и, как писал И. Натали, «свободно и невозбранно тайным образом выпускали моих людей для известных корреспонденцей» [18, л. 13]. Это позволило майору наладить регулярную переписку с В. Тейлсом («повседневно со мною корреспондует») и К. Галани, а также обмениваться письмами с английским послом. Архиепископ К. Галани подтвердил, что Р. Саттон «получил указ от своего короля, дабы почитал интерес царского величества при Порте Оттоманской как собственной его королевского величества интерес» [12, л. 14]. Из-за запрета покидать посольский двор И. Натали так и не встретился с англичанином (в одной из реляций он сожалел, что не удалось «собственно мой поклон отдать его превосходителству и изустно просить его асистенцию») [12, л. 14 об.].

12 марта русский посольский двор посетил И. Маврокордато. Во время беседы с ним И. Натали настаивал на второй аудиенции у великого везира, чтобы сообщить дополнительные сведения о нанесенных татарами и запорожскими казаками «обидах». Поинтересовался он и подготовкой ответа на грамоты Петра I. И. Маврокордато сообщил майору, что «хотя содержание грамоты царского величества в которой изображен марш войск ево, отчасти тяжело, однакож мир будет продолжен, а другая грамота, в которой содержание касаетца до татар, дело лехкое» [11, л. 8 об.]. В конце марта османская армия во главе с султаном и великим везиром выступила из Стамбула и расположилась лагерем близ 
Дауд-поля. В. Тейлс отметил, что И. Натали не только запретили «видеть сей выход», но и писать ко двору [48, с. 278].

Английский посол Р. Саттон, выполняя распоряжение своего правительства, постарался представить Высокой Порте «в наилучшем свете» вступление русских войск в Померанию и заверить в отсутствии у царя намерений вмешиваться во внутренние дела Польши. Согласно его донесениям, беседы с рейс-эфенди и великим везирем сгладили недовольство, вызванное нарушением одного из условий Адрианопольского договора [24, л. 254-255]. Однако, по словам В. Тейлса, англичанин в ответ на попытку объяснить великому везиру причины, по которым царь был вынужден приказать своим войскам идти через Польшу в Померанию, получил совет не вмешиваться, так как Порта обо всем происходящем «довольно известна» [48, с. 279].

11 апреля 1716 г. майора «назад отослали с гордым ответом» [48, с. 280]. Высокая Порта была готова расследовать набеги, покарать виновных и вернуть награбленное имущество, однако ожидала от царя ответных мер в наказании казаков, совершивших рейд под Азов. Османское правительство не разрешило России иметь резидента в Стамбуле и попрежнему настаивало на строгом соблюдении условия Адрианопольского договора об отсутствии войск в польских землях («ибо сей пункт в мирном трактате главным почтен») [48, c. 281]. Однако полученные из разных источников в Стамбуле сведения подтвердили предположение русского правительства, что силы Османской империи в ближайшее время будут направлены на войну с Венецией и поэтому вмешательство царя в польские дела не станет для Высокой Порты поводом объявить войну России.

К концу 1717 г. во внешней политике как России, так и Османской империи наметились серьезные изменения. На фоне сближения России с Францией, наметившегося во время заграничного путешествия Петра I (1716-1717), нарастало напряжение в отношениях с Данией, Англией, Ганновером и Империей. Этому способствовал «мекленбургский вопрос», связанный с введением и пребыванием русских войск на территории Мекленбурга после подписания Петром I союзного договора с герцогом Карлом-Леопольдом (28 марта 1716 г.) [23, с. 334-339; 25 , с. 140-162]. Между тем секретные контакты русского правительства со шведским министром Г.Г. Герцем показали готовность Швеции начать мирные переговоры с Россией. В начале 1718 г. Я.В. Брюс и А.И. Остерман выехали в Финляндию для встречи с представителями Карла XII [51, с. 201].

Подходил к концу военный конфликт и на юге Европы. В Санкт-Петербурге опасались, что после подписания мирного договора с Венецией и Империей Высокая Порта может обратить оружие против России. Это отмечали и европейские дипломаты при царском дворе. В декабре 1717 г. английский резидент Джордж Маккензи доносил своему правительству, что в российской столице распространились слухи о намерении императора заключить мир с Высокой Портой и что «...царь не мог скрыть причиненного ему этим беспокойства» $[17$, с. 269]. В мае 1718 г. в г. Пожареваце (Пассаровице) начался мирный конгресс, на котором медиаторами выступили Р. Саттон и Я. Кольер. С.А. Фейгина отметила, что «английские представители прилагали там все усилия, чтобы вызвать новую русско-турецкую войну» [51, с. 230].

В марте 1718 г. в Россию прибыл турецкий посланник Мустафа-ага [38]. 4 мая он достиг Санкт-Петербурга, где состоялись его аудиенции у канцлера и вице-канцлера. Мустафа-ага вручил Г.И. Головкину грамоту («лист») великого везира Нишанджи Мехмеда-паши с сообщением о намерении Высокой Порты вступить в мирные переговоры с австрийцами и предложением прислать русского представителя на конгресс, чтобы содействовать возвращению князю Ф. Ракоци престола Трансильвании [33]. В конце июня ага отправился обратно в Стамбул с ответными листами Г.И. Головкина и П.П. Шафирова великому везиру [1, с. 323]. П.П. Шафиров, помимо прочего, просил Мехмеда-пашу (с которым познакомился во время своего пребывания в Стамбуле) «в милости своей содержать» посланного с грамотами к османскому двору подполковника И. Натали [34, л. 56].

Еще в декабре 1717 г. рагузинец был вызван для «некоторой посылки» в Москву [16]. Надо полагать, что новый повод для от- 
правки гонца в Стамбул дали опустошительные набеги турецких подданных на пограничные российские города. Осенью 1717 г. в Санкт-Петербурге ходили слухи о «почти невероятном разорении» окрестностей Казани 30-тысячным отрядом татар, разрушении семи городов и многих деревень, уводе 50000 человек в рабство [8, с. 243-244]. Зимой Посольский приказ занимался подготовкой поездки И. Натали: определяли состав сопровождающих и их жалованье, снова собирали меха и покупали венецианские червонцы. По-видимому, из-за визита турецкого аги отправку подполковника к османскому двору задержали на несколько месяцев. И. Натали вызвали в Санкт-Петербург, из которого он выехал 26 мая 1718 г. с подготовленными для поездки документами (грамоты султану и великому везиру, инструкция, «промемория о секретных делах», паспорт и т. д.). Подполковнику также были переданы копии Прутского и Адрианопольского мирных договоров и доставленных им в 1716 г. к царскому двору грамот султана и везира [42, л. 106].

Как и в 1715 г., И. Натали надлежало вручить великому везиру грамоты Петра I о многократных набегах на пограничные земли и настаивать на создании комиссии для расследования. А.Л. Никифоров обратил внимание на «примирительный» тон этих грамот [24, c. 258-259]. Он отметил, что русское правительство хотело любой ценой сохранить мир с Османской империей. Поэтому крайней ответной мерой в случае продолжения набегов с турецкой стороны стало бы разрешение пострадавшему приграничному населению предпринимать ответные походы [24, с. 259].

Согласно инструкции, И. Натали следовало: «Попросить у Порты послать ко двору нашего нарочно посланного; а с посланным секретно писать цифирью о тамошнем их состоянии и войне с цесарем и Венецией» $[18$, л. 22]. В случае провала мирных переговоров османов с венецианцами и австрийцами подполковнику предписывалось более жестко настаивать на претензиях русского правительства. И. Натали также поручили сообщить о скором прибытии царского посла, готового не только участвовать в переговорах с австрийцами, но и остаться на постоянной резиденции в Стамбуле.
Вторая поездка И. Натали в Османскую империю оказалась короче первой. Он прибыл к Высокой Порте до возвращения Мустафыаги, но уже после завершения работы мирного конгресса. 10 (21) июля 1718 г. был подписан Пожаревацкий (Пассаровицкий) мир. Первые известия о заключении мира дошли до И. Натали уже в Бендерах, куда он прибыл 30 июля 1718 г. [14, л. 158]. 5 сентября подполковник достиг Адрианополя, где в то время находились султан и правительство. В начале года предложившего царю прислать представителя на конгресс Нишанджи Мехмеда-пашу на посту великого везира сменил Невшехирли Дамад Ибрагим-паша.

В Адрианополе после встречи с новым великим драгоманом Григорием Гикой И. Натали был дважды принят Ибрагимом-пашой. Великий везир объявил подполковнику об отправке в Азов комиссара для расследования набегов и обещал сурово наказать виновных. Во время второй аудиенции обсуждался вопрос о пребывании русских войск в Польше. Великий везир дал понять, что некие недоброжелатели стараются внести раскол в дружеские отношения между царем и султаном, «но мы о том их не слушаем, наипаче желаем мира» [14, л. 157].

И. Натали не позволили дождаться царского министра, о скором прибытии которого он известил Порту. Не помогло и содействие В. Тейлса, попытавшегося заручиться поддержкой у муфти. И. Натали доносил, что «как он, Телс, будучи у муфтия домогался, чтоб ево Наталия так скоро ехать от Порты не понуждали, но позволили б ему тамо быть еще до указу царского величества» [15, л. 174 об.]. Ибрагим-паша уклонился от прямого ответа на вопрос, сможет ли этот министр остаться на постоянной резиденции в Стамбуле («везирь на то во ответ ему сказал короткими словами, что когда тот царского величества министр к ним прибудет, то они с ним будут говорить») [15, л. 174-174 об.].

24 сентября И. Натали был отправлен с ответными грамотами в Россию. До Бендер его сопровождал капычи-баша ${ }^{12}$, который ехал в Азов, чтобы возглавить комиссию для расследования приграничных инцидентов [15, л. 174]. Через год, в октябре 1719 г., газета «Ведомости» опубликовала сообщение о ме- 
pax, предпринятых капычи-башой и азовским пашой для розыска в Крыму и на Кубани угнанных из Казанской и Азовской губерний «российских пленных людей» $[5, \text { с. } 342]^{13}$.

В Бендерской крепости И. Натали получил известия о направлявшемся к султану царском после («...будто тот посланник царского величества едет в тысяче человеках»). Коллегия иностранных дел намеревалась направить к Порте гвардии капитана Ивана Горохова, который с ноября 1714 г. представлял интересы царя при великом гетмане литовском Л.К. Поцее. Однако И. Горохов до османской столицы так и не доехал. В пути он серьезно заболел и надолго задержался в Киеве [24, с. 259]. В ноябре 1718 г. было решено новым посланником отправить опытного А.И. Дашкова.

Результаты. В середине 1710-х гг. Петpy I, который стремился играть более активную роль в европейской политике, необходима была уверенность в безопасности южных рубежей своего государства. Анализ поставленных перед И. Натали задач показывает, что русское внешнеполитическое ведомство опасалось, что новый военный конфликт с Османской империей может начаться из-за нарушений условий Адрианопольского мирного договора, связанных с пограничными столкновениями, а также русской активностью в Польше и Померании. Результаты поездки И. Натали не ограничивались вручением великому везиру царских грамот и доставкой ответа Высокой Порты. Полученные им из разных источников сведения показали, что ослабленная военными действиями в Средиземноморье Османская империя так же, как и Россия, была заинтересована в сохранении мирных отношений.

\section{ПРИМЕЧАНИЯ}

${ }^{1}$ Исследование выполнено при поддержке РФФИ, проект № 18-09-00721.

2 Данное условие было включено уже в Прутский договор (1711). Тем не менее русское правительство надеялось, что Порта позволит оставить в Стамбуле если не посла, то хотя бы резидента или посольского секретаря. 25 октября 1713 г. в СанктПетербурге был подписан указ о назначении секретарем дьяка Л.Т. Протопопова. В начале 1714 г. он прибыл в Стамбул. Высокая Порта отказалась его принять, и Л.Т. Протопопов был вынужден уехать вместе с послами [2, с. 135-138].

${ }^{3}$ Вместе с царем и с руководством внешнеполитического ведомства майор проследовал из Санкт-Петербурга в Ревель. В российскую столицу он вернулся только в августе [47, л. 6-6 об.].

${ }^{4}$ В 1715 г. плохо знавшему русский язык рагузинцу И. Натали посольскую переписку указали вести на итальянском.

5 По этому договору царь брал обязательство содействовать Ганноверу в присоединении Бремена и Вердена. России гарантировалось приобретение Ингрии, Карелии и Эстляндии с Ревелем [22, с. 31-35]. В тексте договора Георг I именовался также королем Великобритании. Однако парламент не ратифицировал это соглашение, и Англия не вступила в союз с Россией. Тем не менее с марта 1716 г. Б.И. Куракин в Лондоне вел переговоры с английскими и ганноверскими министрами о заключении договоров о союзе, гарантии и торговле [25, с. 122-124].

${ }^{6}$ В черновике цель похода русской армии Померания - была зачеркнута, и вместо нее вписана Германия.

7 В апреле 1715 г. В. Тейлс выехал вместе с османским двором и армией в Адрианополь [48, c. 224].

${ }^{8}$ Волошанин Дмитриев Константин, начавший свою службу в Посольском приказе в 1705 г. с должности курьера [7, с. 131], ездил в Стамбул вместе с И. Натали и в 1718 году.

${ }^{9}$ В своих мемуарах В. Тейлс перечислил поставленные Посольским приказом перед И. Натали задачи: передать грамоты Высокой Порте о набегах, добиваться разрешения на резидента или секретаря в Стамбуле, информировать османов о вводе русских войск в Польшу и т. д. [48, с. 270-271].

10 Чауш - служитель, выполнявший особые поручения.

${ }^{11}$ Галата (итал. Galata) - северное предместье Стамбула, основной торговый район города, где селились христиане. Там же находились резиденции европейских дипломатов.

12 Капычи-баша (точнее капьджибаши) глава привратников, дворцовый служащий, выполняющий обязанности порученца по важным делам.

13 С российской стороны комиссарами были назначены бригадир Петр Измайлов и полковник Иван Тевяшов.

\section{СПИСОК ЛИТЕРАТУРЫ}

1. Агеева, О. Г. Дипломатический церемониал императорской России: XVIII век / О. Г. Агеева. - М. : Новый Хронограф, 2013. - 928 с. 
2. Базарова, Т. А. Русские дипломаты при османском дворе : Статейные списки П. П. Шафирова и М. Б. Шереметева 1711 и 1712 гг. : (Исследование и тексты) / Т. А. Базарова. - СПб. : Историческая иллюстрация, 2016. - 864 с.

3. Базарова, Т. А. Русско-британское дипломатическое противостояние начала 1710-х годов : По материалам фонда Походной канцелярии А. Д. Меншикова Научно-исторического архива СПбИИ РАН / Т. А. Базарова // Санкт-Петербург - Великобритания, XVIII-XXI в. - СПб. : Европейский дом, 2014. C. $232-244$.

4. Бантыш-Каменский, Н. Н. Обзор внешних сношений России (по 1800 год). [В 4 ч.]. Ч. 1 / Н. Н. Бантыш-Каменский. - М. : Тип. Э. Лисснера и Ю. Романа, 1894. - 304 с.

5. Ведомости времени Петра Великого: Впамять 200-летия первой русской газеты. - М. : Синодальная тип., 1906.-Вып. 2 : 1708-1719 гг.-98,373, XXIV с.

6. Грамота Петра I прусскому королю Фридриху-Вильгельму I (копия), 29 июля 1715 г. // Архив Санкт-Петербургского института истории Российской академии наук (Архив СПбИИ РАН). Кол. 270. - Оп. 1. - Д. 79. - Л. 69-73.

7. Гуськов, А. Г. Материалы к справочнику о служащих Посольского приказа (начало XVIII в.) / А. Г. Гуськов // Вспомогательные исторические дисциплины в современном научном знании : материалы XXXI Междунар. науч. конф., Москва, 12-14 апр. 2018 г. - М. : ИВИ РАН, 2018. - С. 129-131.

8. Документы, относящиеся до пребывания царя Петра I во Франции за апрель и май месяцы 1717 г. // Сборник Императорского русского исторического общества. - СПб. : Тип. Имп. Академии наук, 1881. - Т. 34. - С. 123-398.

9. Донесение И. Натали (перевод), 11 февраля 1716 г. // Российский государственный архив древних актов (РГАДА). - Ф. 89. - Оп. 1. 1716 г. - Д. 2. Л. 10-11 об.

10. Донесение И. Натали (перевод), 12 марта 1716 г. // РГАДА. - Ф. 89. - ОП. 1. 1716 г. - Д. 2. Л. $12-13$.

11. Донесение И. Натали (перевод), 18 февраля 1716 г. // РГАДА. - Ф. 89. - Оп. 1. 1716 г. - Д. 2. Л. 7-10.

12. Донесение И. Натали (перевод), 22 марта 1716 г. // РГАДА. - Ф. 89. - ОП. 1. 1716 г. - Д. 2. Л. 14-15 об.

13. Донесение И. Натали в Посольскую канцелярию (перевод), 28 декабря 1715 г. // РГАДА. Ф. 89. - Оп. 1. 1715 г. - Д. 6. - Л. 75-76.

14. Донесение И. Натали Г.И. Головкину и П.П. Шафирову (перевод), 16 сентября 1718 г. // РГАДА. - Ф. 89. - Оп. 1. 1718 г. - Д. 6. - Л. 153-159.

15. Донесение И. Натали, 20 ноября 1718 г. // РГАДА. - Ф. 89.-Оп. 1. 1718 г. - Д. 6. - Л. 174-175 об.
16. Донесение И.Б. Вейсбаха из Нежина, 7 января 1718 г. // РГАДА. - Ф. 89. - ОП. 1. 1718 г. - Д. 6. Л. 1-1 об.

17. Донесения и другие бумаги английских послов, посланников и резидентов при русском двоpe c 1711 г. по 1719 г. // Сборник Императорского русского исторического общества. - СПб. : Тип. Имп. Академии наук, 1888. - Т. 61. -610 с.

18. Инструкция И. Натали, 26 мая 1718 г. // РГАДА. - Ф. 89. - ОП. 1. 1718 г. - Д. 6. - Л. 12-31.

19. Инструкция Посольской канцелярии (черновик), 6 октября 1715 г. // РГАДА. - Ф. 89. - Оп. 1. 1715 г. - Д. 6. - Л. 16-29 об.

20. Крылова, Т. К. Русская дипломатия на Босфоре в 1711-1714 гг. / Т. К. Крылова // Международные связи России в XVII-XVIII вв.: (Экономика, политика и культура) : сб. статей. -М. : Наука, 1966. - С. 410-446.

21. Крылова, Т. К. Русско-турецкие отношения во время Северной войны / Т. К. Крылова // Исторические записки. - 1941. - Т. 10. - С. 250-279.

22. Мартенс, Ф. Ф. Собрание трактатов и конвенций, заключенных Россией с иностранными державами. [В 15 т.]. Т. IX. Трактаты с Англией (17081801) / Ф. Ф. Мартенс. - СПб. : Тип. М-ва Путей Сообщения (А. Бенке), 1892. - 563 с.

23. Молчанов, Н. Н. Дипломатия Петра Великого / Н. Н. Молчанов. - 3-е изд. - М. : Междунар. отношения, 1990. $-448 \mathrm{c}$.

24. Никифоров, Л. А. Внешняя политика России в последние годы Северной войны: Ништадтский мир / Л. А. Никифоров. - М. : Изд-во Академии наук СССР, 1959. - 498 с.

25. Никифоров, Л. А. Русско-английские отношения при Петре I / Л. А. Никифоров. - М. : Госполитиздат, 1950. - $279 \mathrm{c}$.

26. Норвич, Дж. Дж. История Венецианской республики / Дж. Дж. Норвич ; пер. с англ. И. Летберг, Н. Омельянович, Ю. Федоренко. - М. : АСТ : АСТ Москва, 2010. - 864 с.

27. Орешкова, С. Ф. Русско-турецкие отношения в начале XVIII в. / С. Ф. Орешкова. - М. : Наука, 1971. $-205 \mathrm{c}$.

28. Орешкова, С. Ф. Немировский конгресс: От двусторонних османо-российских отношений к Восточному вопросу / С. Ф. Орешкова. - М. : Ин-т востоковедения РАН, 2015. - 291 с.

29. Отчет И. Натали о расходах (копия), 10 января 1719 г. // РГАДА. - Ф. 89. - ОП. 1. 1715 г. - Д. 6. Л. 13-15 об.

30. Офицерские сказки первой четверти XVIII века. Полевая армия : сб. док. [В 2 т.]. Т. 1 / сост. К. В. Татарников.- М. : Старая Басманная, 2015. $-1352 \mathrm{c}$.

31. Письма и бумаги императора Петра Великаго. - Т. 12, вып. 2 (Июль - декабрь 1712 г.). - М. : Наука, 1977. - 629 с. 
32. Письма и бумаги императора Петра Великого. - Т. 13, вып. 1 (Январь - июнь 1713 г.). - М. : Наука, 1992. - $480 \mathrm{c}$.

33. Письмо («лист») великого везира Г. И. Головкину (перевод), 1718 г. // РГАДА. - Ф. 89. - Оп. 1. 1718 г. - Д. 5. - Л. 29-31 об.

34. Письмо («лист») П.П. Шафирова великому везиру (перевод), 30 июня 1718 г. // РГАДА. -Ф. 89. Оп. 1. 1718 г. - Д. 5. - Л. 54-56.

35. Письмо Б.И. Куракина Петру I (копия), 25 января 1715 г. // РГАДА. - Ф. 9. - Отд. 2. - Кн. 23. Л. $550-554$.

36. Письмо П.П. Шафирова Р. Саттону (черновик), 6 октября 1715 г. // РГАДА. - Ф. 89. - Оп. 1. 1715 г. - Д. 6. - Л. 53-57 об.

37. Полное Собрание Законов Российской Империи: Собрание первое: С 1649 по 12 декабря 1825 года. Т. 5. 1713-1719. - СПб. : Тип. ІІ Отд. собств. Е.И.В. канц., 1830. -782 с.

38. Приезд в Санкт-Петербург и отпуск турецкого посланника Мустафы-аги, 16 февраля - июль 1718 г. // РГАДА. - Ф. 89. - ОП. 1.1718 г. - Д. 5. - Л. 1-66 об.

39. «Промемория что писать на италианском языке к маеору Наталию» (черновик), 1716 г. // РГАДА. Ф. 89. - Оп. 1. 1716 г. - Д. 2. - Л. 1-6.

40. Распоряжение Г.И. Головкина и П.П. Шафирова, 30 сентября 1715 г. // РГАДА. - Ф. 89. Оп. 1. 1715 г. - Д. 6. - Л. 1.

41. Распоряжение Г.И. Головкина и П.П. Шафирова, 6 октября 1715 г. // РГАДА. -Ф. 89. - Оп. 1. 1715 г. - Д. $6 .-$ Л. 2.

42. «Реестр, что отправлено с Наталием при отпуске его... в Турскую землю», 26 мая 1718 г. // РГАДА. -Ф. 89.-ОП. 1. 1718 г.- Д. 6. - Л. 106-106 об.

43. «Реэстр экспедиции в Турскую землю» И. Натали, 1715 г. // РГАДА. - Ф. 89. - Оп. 1.1715 г.Д. 6. - Л. 64-64 об.

44. Секретная мемория для И. Натали (черновик), 1715 г. // РГАДА. - Ф. 89. - Оп. 1. 1715 г. Д. 6. - Л. 3-4.

45. Соловьев, С.М. Сочинения. В 18 кн. Кн. IX. История России с древнейших времен. Т. 17-18 / С. М. Соловьев. - М. : Мысль, 1993. - 671 с.

46. Справка Посольского приказа (черновик), 1718 г. // РГАДА. - Ф. 89. - ОП. 1. 1715 г. -Д. 6. - Л. 7-9.

47. Справка Посольской канцелярии об экспедиции И. Натали, 1718 г. // РГАДА. - Ф. 89. - Оп. 1. 1715 г. - Д. 6. - Л. 6-6 об.

48. Тейльс, В. Известия, служащия к истории Карла ХІІ, короля шведскаго... / В. Тейльс ; пер. с фр. А. А. Тейльса. - М. : Университетская тип., у В. Окорокова, 1798. - 468 с.

49. Торопицын, И. В. Набеги кубанских татар на Россию в 1715 году / И. В. Торопицын // Козацька спадщина : Альманах Інституту суспільних досліджень. - Дніпропетровськ, 2008. - Вип. 4. -С. 72-78.
50. Указ Петра I Б.П. Шереметеву (копия), 27 июля 1715 г. // Архив СПбИИ РАН. - Кол. 270. ОП. 1. - Д. 79. - Л. 68.

51. Фейгина, С. А. Аландский конгресс: Внешняя политика России в конце Северной войны / С. А. Фейгина. - М. : Изд-во АНСССР, 1959. - 548 с.

\section{REFERENCES}

1. Ageeva O.G. Diplomaticheskiy tseremonial imperatorskoy Rossii: XVIII vek [Diplomatic Ceremony of Imperial Russia: The $18^{\text {th }}$ Century]. Moscow, Novyy Khronograf Publ., 2013. 928 p.

2. Bazarova T.A. Russkie diplomaty pri osmanskom dvore: Stateynye spiski P. P. Shafirova $i$ M. B. Sheremeteva 1711 i 1712 gg.: (Issledovanie $i$ teksty) [Russian Diplomats at the Ottoman Court: Article Lists by Petr Shafirov and Mikhail Sheremetev in 1711 and 1712 (Research and Documents)]. Saint Petersburg, Istoricheskaya illustratsiya Publ., 2016. 864 p.

3. Bazarova T.A. Russko-britanskoe diplomaticheskoeprotivostoyanie nachala 1710-kh godov: Po materialam fonda Pokhodnoy kantselyarii A. D. Menshikova Nauchno-istoricheskogo arkhiva SPbII RAN [Russian-British Diplomatic Confrontation of the Early 1710s: Based on the Materials of the Fund of Field Chancellery of A.D. Menshikov from the Scientific and Historical Archive of Saint Petersburg Institite, RAS]. Sankt-Peterburg Velikobritaniya. XVIII-XXI vv. [St. Petersburg Great Britain. The $18^{\text {th }}-21^{\text {st }} \mathrm{cc}$.]. Saint Petersburg, Evropeyskiy dom Publ., 2014, pp. 232-244.

4. Bantysh-Kamenskiy N.N. Obzor vneshnikh snosheniy Rossii (po 1800 god). V 4 ch. CH. 1 [Review of External Relations of Russia (till 1800). In 4 Parts. Part 1]. Moscow, E. Lissner and J. Roman Publ., 1894. $304 \mathrm{p}$.

5. Vedomosti vremeni Petra Velikogo: $V$ pamyat 200-letiya pervoy russkoy gazety [Vedomosti of Peter the Great's Time: In Memory of the $200^{\text {th }}$ Anniversary of the First Russian Newspaper]. Moscow, Synodalnaya tip., 1906, iss. 2: 1708-1719, 98, 373, XXIV p.

6. Gramota Petra I prusskomu korolyu FridrikhuVilgelmu I (kopiya), 29 iyulya 1715 g. [The Charter of Peter I to the Prussian King Friedrich Wilhelm I (Copy), July 29, 1715]. Arkhiv Sankt-Peterburgskogo instituta istorii Rossiyskoy akademii nauk [Archive of Saint Petersburg Institute of History, RAS], Coll. 270, Op. 1, D. 79, L. 69-73.

7. Guskov A.G. Materialy k spravochniku o sluzhashchikh Posolskogo prikaza (nachalo XVIII v.) [Materials to the Reference Book about Employees of the Ambassadorial Prikaz (the Beginning of the $18^{\text {th }}$ Century)]. Vspomogatelnye istoricheskie distsipliny 
$v$ sovremennom nauchnom znanii: materialy XXXI Mezhdunar. nauch. konf., Moskva, 12-14 apr. $2018 \mathrm{~g}$. [Auxiliary Historical Disciplines in Modern Scientific Knowledge: Proceedings of the $31^{\text {th }}$ International Scientific Conference (Moscow, April 1214, 2018)]. Moscow, IVI RAN Publ., 2018, pp. 129-131.

8. Dokumenty, otnosyashchiesya do prebyvaniya tsarya Petra I vo Frantsii za aprel i may mesyatsy 1717 g. [The Documents Related to the Stay of Tsar Peter I in France in April and May of 1717]. Sbornik Imperatorskogo russkogo istoricheskogo obshchestva [Collection of Imperial Russian Historical Society]. Saint Petersburg, Tip. Imp. Akademii nauk, 1881, vol. 34, pp. 123-398.

9. Donesenie I. Natali (perevod), 11 fevralya 1716 g. [Report of I. Natali (Translation), February 11, 1716]. Rossiyskiy gosudarstvennyy arkhiv drevnikh aktov [The Russian State Archive of Ancient Acts], F. 89, Op. 1, 1716, D. 2, L. 10-11 ob.

10. Donesenie I. Natali (perevod), 12 marta 1716 g. [Report of I. Natali (Translation), March 12, 1716]. Rossiyskiy gosudarstvennyy arkhiv drevnikh aktov [The Russian State Archive of Ancient Acts], F. 89, Op. 1, 1716, D. 2, L. 12-13.

11. Donesenie I. Natali (perevod), 18 fevralya 1716 g. [Report of I. Natali (Translation), February 18, 1716]. Rossiyskiy gosudarstvennyy arkhiv drevnikh aktov [The Russian State Archive of Ancient Acts], F. 89, Op. 1, 1716, D. 2, L. 7-10.

12. Donesenie I. Natali (perevod), 22 marta 1716 g. [Report of I. Natali (Translation), March 22, 1716]. Rossiyskiy gosudarstvennyy arkhiv drevnikh aktov [The Russian State Archive of Ancient Acts], F. 89, Op. 1, 1716, D. 2, L. 14-15 ob.

13. Donesenie I. Natali v Posolskuyu kantselyariyu (perevod), 28 dekabrya 1715 g. [Report of I. Natali to the Polish Ambassadorial Office (Translation), December 28, 1715]. Rossiyskiy gosudarstvennyy arkhiv drevnikh aktov [The Russian State Archive of Ancient Acts], F. 89, Op. 1, 1715, D. 6, L. 75-76.

14. Donesenie I. Natali G.I. Golovkinu i P.P. Shafirovu (perevod), 16 sentyabrya $1718 \mathrm{~g}$. [Report of I. Natali to G.I. Golovkin and P.P. Shafirov (Translation), September 16, 1718.]. Rossiyskiy gosudarstvennyy arkhiv drevnikh aktov [The Russian State Archive of Ancient Acts], F. 89, Op. 1, 1718, D. 6, L. 153-159.

15. Donesenie I. Natali, 20 noyabrya $1718 \mathrm{~g}$. [Report of I. Natali, November 20, 1718.]. Rossiyskiy gosudarstvennyy arkhiv drevnikh aktov [The Russian State Archive of Ancient Acts], F. 89, Op. 1, 1718, D. 6, L. 174-175 ob.

16. Donesenie I.B. Veysbakha iz Nezhina, 7 yanvarya $1718 \mathrm{~g}$. [Report of J.B. Weissbach from Nezhin, January 7, 1718]. Rossiyskiy gosudarstvennyy arkhiv drevnikh aktov [The Russian State Archive of Ancient Acts], F. 89, Op. 1, 1718, D. 6, L. 1-1 ob.
17. Doneseniya i drugie bumagi angliyskikh poslov, poslannikov i rezidentov pri russkom dvore s 1711 g. po 1719 g. [Reports and Other Papers of English Ambassadors, Envoys and Residents at the Russian Court from 1711 to 1719]. Sbornik Imperatorskogo russkogo istoricheskogo obshchestva [Collection of Imperial Russian Historical Society]. Saint Petersburg, Tip. Imp. Akademii nauk, 1888, vol. 61. 610 p.

18. Instruktsiya I. Natali, 26 maya $1718 \mathrm{~g}$. [Instruction for I. Natali, May 26, 1718.]. Rossiyskiy gosudarstvennyy arkhiv drevnikh aktov [The Russian State Archive of Ancient Acts], F. 89, Op. 1, 1718, D. 6, L. 12-31.

19. Instruktsiya Posolskoy kantselyarii (chernovik), 6 oktyabrya $1715 \mathrm{~g}$. [Instruction of Ambassadorial Office (Draft Copy), October 6, 1715]. Rossiyskiy gosudarstvennyy arkhiv drevnikh aktov [The Russian State Archive of Ancient Acts], F. 89, Op. 1, 1715, D. 6, L. 16-29 ob.

20. Krylova T.K. Russkaya diplomatiya na Bosfore v 1711-1714 gg. [The Russian Diplomacy on Bosphorus in 1711-1714]. Mezhdunarodnye svyazi Rossii v XVII-XVIII vv.: (Ekonomika, politika $i$ kultura): Sbornik statey [International Relations of Russia in the $17^{\text {th }}-18^{\text {th }}$ Centuries: (Economy, Policy and Culture): Collection of Articles]. Moscow, Nauka Publ., 1966, pp. 410-446.

21. Krylova T.K. Russko-turetskie otnosheniya vo vremya Severnoy voyny [The Russian-Turkish Relations during the Great Northern War]. Istoricheskie zapiski [Historical Notes], 1941, vol. 10, pp. 250-279.

22. Martens F.F. Sobranie traktatov i konventsiy, zaklyuchennykh Rossiey s inostrannymi derzhavami: v 15 t. T. IX: Traktaty s Angliey (1708-1801) [A collection of Treaties and Conventions Concluded by Russia with Foreign Powers. In 15 vols. Vol. 9: Treaties with England. 1708-1801]. Saint Petersburg, Tip. M-va Putey Soobshcheniya (A. Benke), 1892. 563 p.

23. Molchanov N.N. Diplomatiya Petra Velikogo [Peter the Great's Diplomacy]. Moscow, Mezhdunarodnye otnosheniya Publ., 1990. 448 p.

24. Nikiforov L.A. Vneshnyaya politika Rossii v poslednie gody Severnoy voyny: Nishtadtskiy mir [Russia's Foreign Policy in the Last Years of the Great Northern War: The Nystadt Peace]. Moscow, Izd-vo Akademii nauk SSSR, 1959. 498 p.

25. Nikiforov L.A. Russko-angliyskie otnosheniya pri Petre I [Russian-English Relations under Peter I]. Moscow, Gospolitizdat Publ., 1950. 279 p.

26. Norwich J.J. Istoriya Venetsianskoy respubliki [A History of Venice]. Moscow, AST: AST Moskva Publ., 2010. 864 p.

27. Oreshkova S.F. Russko-turetskie otnosheniya $v$ nachale XVIII v. [Russian-Turkish Relations in the 
Early 18th Century]. Moscow, Nauka Publ., 1971. 205 p.

28. Oreshkova S.F. Nemirovskiy kongress:

Ot dvustoronnikh osmano-rossiyskikh otnosheniy $k$ Vostochnomu voprosu [Nemirovsky Congress: From Bilateral Ottoman-Russian Relations to the Eastern Question]. Moscow, Institut vostokovedeniya Publ., 2015. $291 \mathrm{p}$.

29. Otchet I. Natali o raskhodakh (kopiya), 10 yanvarya 1719 g. [H. Natalie's Report on the Expenditure of Money (Copy), January 10, 1719]. Rossiyskiy gosudarstvennyy arkhiv drevnikh aktov [The Russian State Archive of Ancient Acts], F. 89, Op. 1, 1715, D. 6, L. 13-15 ob.

30. Tatarnikov K.V., ed. Ofitserskie skazki pervoj chetverti XVIII veka. Polevaya armiya: Sbornik dokumentov. V 2 t. T. 1 [Officer's Stories of the First Quarter of the 18th Century. Field Army: Collection of Documents. In 2 vols. Vol. 1]. Moscow, Staraya Basmannaya Publ., 2015. 1352 p.

31. Pisma i bumagi imperatora Petra Velikago. T. 12, vyp. 2 (Iyul - dekabr 1712 g.) [Letters and Papers of Emperor Peter the Great. Vol. 12, Iss. 2: (July-December 1712)]. Moscow, Nauka Publ., 1977. 629 p.

32. Pisma i bumagi imperatora Petra Velikago. T. 13, vyp. 1 (yanvar-iyun 1713 g.) [Letters and Papers of Emperor Peter the Great. Vol. 13, Iss. 1: (January-June 1713)]. Moscow, Nauka Publ., 1992. 480 p.

33. Pismo («list») velikogo vezira G. I. Golovkinu (perevod), 1718 g. [Letter (Sheet) by the Great Vezir to G.I. Golovkin (Translation), 1718]. Rossiyskiy gosudarstvennyy arkhiv drevnikh aktov [The Russian State Archive of Ancient Acts], F. 89, Op. 1, 1718, D. 5, L. 29-31 ob.

34. Pismo («list») P.P. Shafirova velikomu veziru (perevod), 30 iyunya $1718 \mathrm{~g}$. [Letter (Sheet) by P.P. Safirov to the Great Vezir (Translation), June 30, 1718]. Rossiyskiy gosudarstvennyy arkhiv drevnikh aktov [The Russian State Archive of Ancient Acts], F. 89, Op. 1, 1718, D. 5, L. 54-56.

35. Pismo B.I. Kurakina Petru I (kopiya), 25 yanvarya 1715 g. [Letter by B.I. Kurakin to Peter I (Copy), January 25, 1715]. Rossiyskiy gosudarstvennyy arkhiv drevnikh aktov [The Russian State Archive of Ancient Acts], F. 9, Otd. 2, Kn. 23, L. 550-554.

36. Pismo P.P. Shafirova R. Sattonu (chernovik), 6 oktyabrya 1715 g. [Letter by P.P. Shafirov to R. Sutton (Draft Copy), October 6, 1715]. Rossiyskiy gosudarstvennyy arkhiv drevnikh aktov [The Russian State Archive of Ancient Acts], F. 89, Op. 1, 1715, D. 6, L. 53-57 ob.

37. Polnoe Sobranie Zakonov Rossiyskoy Imperii: Sobranie pervoe: S 1649 po 12 dekabrya 1825 goda. T. 5. 1713-1719 [Complete Collection of Laws of the Russian Empire: The First Collection: From 1649 to December 12, 1825. Vol. 5: 1713-1719]. Saint
Petersburg, Tip. II Otdeleniya sobstv. E.I.V. kantselyarii, $1830.782 \mathrm{p}$.

38. Priezd v Sankt-Peterburg i otpusk turetskogo poslannika Mustafy-agi, 16 fevralya - iyul $1718 \mathrm{~g}$. [Arrival in St. Petersburg and Departure of the Turkish Envoy Mustafa-aga, February 16 - July 1718]. Rossiyskiy gosudarstvennyy arkhiv drevnikh aktov [The Russian State Archive of Ancient Acts], F. 89, Op. 1, 1718, D. 5, L. 1-66 ob.

39. «Promemoriya chto pisat na italianskom yazyke k maeru Nataliyu» (chernovik), 1716 g. [Memorandum on What to Write in the Italian Language for Mayor Natalie"(Draft Copy), 1716.]. Rossiyskiy gosudarstvennyy arkhiv drevnikh aktov [The Russian State Archive of Ancient Acts], F. 89, Op. 1, 1716, D. 2, L. 1-6.

40. Rasporyazhenie G.I. Golovkina i P.P. Shafirova, 30 sentyabrya 1715 g. [Order of G.I. Golovkin and P.P. Shafirov, September 30, 1715]. Rossiyskiy gosudarstvennyy arkhiv drevnikh aktov [The Russian State Archive of Ancient Acts], F. 89, Op. 1, 1715, D. 6, L. 1.

41. Rasporyazhenie G.I. Golovkina i P.P. Shafirova, 6 oktyabrya 1715 g. [Order of G.I. Golovkin and P.P. Shafirov, Oktober 6, 1715]. Rossiyskiy gosudarstvennyy arkhiv drevnikh aktov [The Russian State Archive of Ancient Acts], F. 89, Op. 1, 1715, D. 6, L. 2.

42. «Reestr, chto otpravleno s Nataliem pri otpuske ego... v Turskuyu zemlyu», 26 maya $1718 \mathrm{~g}$. ["The Register of What Was Sent with Natalie at the Time of His Departure... to the Turkish Land", May 26, 1718] Rossiyskiy gosudarstvennyy arkhiv drevnikh aktov [The Russian State Archive of Ancient Acts], F. 89, Op. 1, 1718, D. 6, L. 106-106 ob.

43. «Reestr ekspeditsii v Turskuyu zemlyu» I. Natali, 1715 g. ["The Register of Expedition of H. Natalie to the Turkish Land", 1715]. Rossiyskiy gosudarstvennyy arkhiv drevnikh aktov [The Russian State Archive of Ancient Acts], F. 89, Op. 1, 1715, D. 6, L. 64-64 ob.

44. Sekretnaya memoriya dlya I. Natali (chernovik), $1715 \mathrm{~g}$. [Secret Memorial for H. Natalie (Draft), 1715]. Rossiyskiy gosudarstvennyy arkhiv drevnikh aktov [The Russian State Archive of Ancient Acts], F. 89, Op. 1, 1715, D. 6, L. 3-4.

45. Solovyev S.M. Sochineniya: V 18 kn. Kniga. IX: Istoriya Rossii s drevneyshikh vremen. T. 17-18 [Works: In 18 Books. Book IX: The History of Russia Since Ancient Times. Vols 17-18]. Moscow, Mysl Publ., $1993.671 \mathrm{p}$.

46. Spravka Posolskogo prikaza (chernovik), 1718 g. [Reference of the Ambassadorial Prikaz (Orderin-Charge Department) (Draft Copy), 1718]. Rossiyskiy gosudarstvennyy arkhiv drevnikh aktov [The Russian State Archive of Ancient Acts], F. 89, Op. 1, 1715, D. 6, L. 7-9. 
47. Spravka Posolskoy kantselyarii ob ekspeditsii I. Natali, 1718 g. [Reference of the Ambassadorial Office about the Expedition of H. Natalie, 1718]. Rossiyskiy gosudarstvennyy arkhiv drevnikh aktov [The Russian State Archive of Ancient Acts], F. 89, Op. 1, 1715, D. 6, L. 6-6 ob.

48. Teyls V. Izvestiya, sluzhashchiya $k$ istorii Karla XII, korolya shvedskago... [News for the History of Charles XII, King of Sweden...]. Moscow, Universitetskaya tip. (V. Okorokov), 1798. 468 p.

49. Toropitsyn I.V. Nabegi kubanskikh tatar na Rossiyu v 1715 godu [The Raids of the Kuban Tatars against Russia in 1715]. Kozatska spadshchina:
Al'manakh Institutu suspilnikh doslidzhen [Cossack Heritage: Almanac of the Institute of Social Research]. Dnipropetrovsk, 2008, iss. 4, pp. 72-78.

50. Ukaz Petra I B.P. Sheremetevu (kopiya), 27 iyulya $1715 \mathrm{~g}$. [Decree of Peter I to B.P. Sheremetev (Copy), July 27, 1715]. Arkhiv Sankt-Peterburgskogo instituta istorii Rossiyskoy akademii nauk [Archive of Saint Petersburg Institute of History, RAS], Coll. 270, Op. 1, D. 79, L. 68.

51. Feygina S.A. Alandskiy kongress: Vneshnyaya politika Rossii v kontse Severnoy voyny [Congress of Aland. Russia's Foreign Policy at the End of the Great Northern War]. Moscow, AN SSSR Publ., 1959. 548 p.

\section{Information about the Author}

Tatyana A. Bazarova, Candidate of Sciences (History), Head of Scientific and Historical Archive of Saint Petersburg Institute of History, RAS, Petrozavodskaya St., 7, 197110 Saint Petersburg, Russian Federation, tbazarova@yandex.ru, https://orcid.org/0000-0001-9380-5921

\section{Информация об авторе}

Татьяна Анатольевна Базарова, кандидат исторических наук, заведующая Научно-историческим архивом и группой источниковедения СПбИИ РАН, ул. Петрозаводская, 7, 197110 г. СанктПетербург, Российская Федерация, tbazarova@yandex.ru, https://orcid.org/0000-0001-9380-5921 